\title{
Forbidden Revolutions: David Martin's Encounter with Pentecostalism
}

\author{
David Maxwell ${ }^{1}$
}

Published online: 17 March 2020

(C) The Author(s) 2020

\begin{abstract}
This article illuminates how David Martin's engagement with Pentecostalism represented a significant turning point in his career in both personal and academic terms. It allowed him to come to terms with his own Methodist 'revivalist childhood' and to generate new insights into his pre-existing concerns: insights into the sociological method, the relation of religion to politics, the modernity of religion, and the secularisation thesis. In particular, it brought new energy to his continuing mission to persuade his own sociological profession, along with a liberal-minded intelligentsia, to see the social and political significance of contemporary religious expressions. David wrote with profundity and poignancy about the mentalities and aspirations of ordinary Pentecostal adherents, aware that communities of the poor across the globe aspired to an all-around 'betterment' from on high. His research and mentoring of young scholars inspired those pioneering the anthropology of Christianity in the early 2000s and prompted interventions in debates on the nature of World Christianity.
\end{abstract}

Keywords Anthropology of Christianity $\cdot$ Betterment $\cdot$ Latin America $\cdot$ Pentecostalism $\cdot$ Politics $\cdot$ Power $\cdot$ World Christianity

David Martin's journey into Pentecostalism began in the mid1980s. Although appearing a radical refocus of his intellectual interests this change in direction allowed him to pursue preexisting important themes in his scholarship in a new manner. It prompted new insights into the sociological method, the relation of religion to politics, the modernity of religion, and the secularisation thesis. The latter came about by setting Western secularisation in a global context of revival and religious effervescence that was Pentecostal religion. Here, as David pointed out, was a religious movement amounting to about a quarter of billion people worldwide, identifiable by the 'free and democratic availability of gifts of the spirit'. David's encounter with Pentecostalism was also deeply personal. Although a global phenomenon, his research focussed upon its expression in Latin America which was the first region of the Southern hemisphere to witness a Pentecostal takeoff from the late 1970s onwards. His move to the Southern

${ }^{1}$ D. Martin, Forbidden Revolutions, Pentecostalism in Latin America, Catholicism in Eastern Europe (London: SPCK, 1996) 26, 10-11.

David Maxwell

djm223@cam.ac.uk

1 Ecclesiastical History, Emmanuel College, St Andrews Street, Cambridge, England CB2 3AP, UK
Methodist University in Dallas Fort Worth, Texas, in 1986 brought him into close encounter with his subjects, just across the border. As he discovered, Pentecostals are little disposed to allow researchers the luxury of ethnographic neutrality. Those academics who profess faith find it tested through invitations to preach and testify. And so in due course he was presented with the opportunity to tell his own family's 'story' of struggle, upward mobility, and Non-Conformity, integrating his narrative into the 'Grand Narrative' of salvation in a manner that generated solidarity and heartfelt appreciation from an audience of rural laborers outside of Santiago in Chile. Research on Latin American Pentecostalism thus represented an important turning point in his academic and personal trajectory, allowing him to come to terms with his own Methodist 'revivalist childhood' on both intellectual and emotional levels. ${ }^{2}$

David's three books and numerous articles on Pentecostalism were characterized by great insight into the 'life-worlds' of ordinary believers. He wrote with profundity and poignancy about their mentalities, aspirations, and idioms, his understanding owing much his own religious formation.

\footnotetext{
${ }^{2}$ D. Martin, The Education, of David Martin. The Making of an Unlikely Sociologist. (London: SPCK, 2013) 209-14. I first came across David's Santiago sermon in a draft chapter of an intended book entitled Betterment from on High. Sadly, it was never finished.
} 
As he encountered Pentecostal communities in Chile, Mexico and Brazil he quickly grasped that 'the street preachers and self-employed workers in the informal economy of Latin America were reincarnations of [his] father preaching in Hyde Park and standing proud and independent beside his immaculate taxi'. ${ }^{3}$ But he also brought to the study of Pentecostalism great conceptual sophistication.

The first of David's trilogy of books on Pentecostalism, Tongues of Fire, (1990) was a masterly reinterpretation of the literature on Latin American Protestantism in the light of his own sociological interests. But my favorite is his second book, Forbidden Revolutions. Pentecostalism in Latin America and Catholicism in Eastern Europe (1996), which amounts to an extended version of his F.D. Maurice lectures given at Kings College, London in 1991.

A distillation of his thinking on Pentecostalism, the book brings to the fore David's mission as a sociologist of religion whereby he sought to rescue the lives of ordinary adherents from the condescension of secular-minded sociologists and theologians. ${ }^{4}$ His engagement with Pentecostalism was a continuation of his career-long struggle to persuade his own sociological profession, along with a liberal-minded intelligentsia, to grasp the social and political significance of contemporary religious expressions. ${ }^{5}$ Forbidden Revolutions was written with passion and sardonic wit, animated by entertaining swipes at scholars whose constructs and political preferences forbade them from grasping a world beyond their own.

The key idea of the book was marginality: 'setting up some enclave of protected free space on the margin' which was achieved by severing 'the immemorial bonds tying [Pentecostals] into local hierarchies' and cutting 'the lateral bonds linking them up with their neighbourhood and its norms of behaviour' such as 'corruption, clientship, violence, the abuse and abandonment of women, the neglect of nurture and discipline, and the dissipation of resources, especially on alcohol'. ${ }^{6}$ This was not an escapist, otherworldly strategy but 'principled marginality', standing in a non-conformist tradition of repudiating links between church and state. ${ }^{7}$ Its ' $\log$ ic' as David explained was that Pentecostals 'rightly expect very little from corrupt bureaucracies, or patronage networks, or even rival elites in remote political classes. They believe

\footnotetext{
${ }^{3}$ Martin, Education, 15.

${ }^{4}$ Here I am borrowing a phrase from another eminent son of Methodism, E.P. Thompson, who had is own atypical journey into academia. Thompson shared David's desire to write the poor into history but of course came to controversially different conclusions about popular Methodism. Thompson wrote 'I am seeking to rescue the poor stockinger, the Luddite cropper, the obsolete handloom weaver ... from the condescension of posterity', The Making of the English Working Class (London: Penguin,(1979 [1963]), 13. On Thompson's Methodist formation see J. Cox, Master Narratives of Imperial Missions in J. Scott and G Griffiths (eds.) Mixed Messages: Materiality, Textuality, Missions, (London: Palgrave MacMillan, 2005).

${ }^{5}$ Martin, Education, 4-6, 113, 129-30.

${ }^{6}$ Martin, Forbidden, 59.

${ }^{7}$ Martin, Forbidden, 43, 37.
}

that the only practical and efficient way forward is to create an inviolate social space that they can truly call their own, and where they can with dignity renew themselves. ${ }^{8}$ Viewing his own social and intellectual position within academia as one of marginality David wrote with much depth and understanding about the marginality of others, aware that some of the best and most transformative ideas are conceived far from the university. But the book contains many other riches and is worth citing at length because it is as striking for of the elegance of its prose as it is for the depth of its perceptions.

The opening section of Forbidden Revolutions cleared the ground, creating a conceptual space in which Pentecostalism (and Eastern Orthodoxy) could be properly examined. David exposed the intellectual laziness involved in dismissing Pentecostalism as Fundamentalism. This simple-minded label obscured more than enlightened and covered every form of communal fanaticism as well as several very different versions of conservative religion ... fusing both together under the influence of liberal panic'. ${ }^{9}$ Continuing in the same vein he warned of the danger of reading Southern Pentecostals according to western moral scripts, rendering them disappointing subalterns. Such an approach he argued derived from a world "where moral judgements have been tied up within political attitudes, and our public arena consists of a struggle for rectitude between rival rhetorics. In that struggle, we sort out good guys and bad guys with the aide of these categories, and then project our judgements onto other cultures'. While Liberation Theologians' idealized characterizations of base communities were deemed acceptable 'the rest of the people are merely spoken about. They are described and categorised as political or apolitical, left or right, but we never hear their own voices and would not dream of taking them seriously if we did'. ${ }^{10}$ In a particularly compelling passage, he observed: 'The truth is that most people in the world are too poor for our kind of politics, and in any case they live in a context where our categorizations do not necessarily apply. The nearly half a billion people of Latin America offer a prime instance. Most of them belong to underclasses that struggle for survival while corrupt and remote political classes wrangle over their heads for the spoils of state and nation. In such a situation, evangelicals and Pentecostals are political because they alter what is in their capacity to alter, beginning with themselves, their families and congregations. They bind themselves on rafts of discipline and hope and, so far as is possible, cut themselves off from the corruption and violence around them, most evidently in the political sphere. ${ }^{11}$

In David's view, religion was part of culture and culture should never be reduced to superstructure. If read as a simple reflection of other phenomena scholars overlooked its own

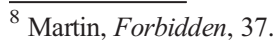

${ }^{9}$ Martin, Forbidden, 5.

${ }^{10}$ Martin, Forbidden, 13.

${ }^{11}$ Martin, Forbidden, 11-12.
} 
innate resources, which were active agents of social change. ${ }^{12}$ Religion was a form of power, which impinged on politics in a great variety of ways. To grasp its full significance the researcher needed a 'capacious understanding of power, including, for example, the condensed sign language of religion and the personal transformations that religion brings about and the implicit models of behaviour and organisation it generates'. ${ }^{13}$ To illustrate his argument he wrote: There are many countries where the whole of society has been so dehumanized and its language about itself so debased that to conserve a personal world against relentless encroachment is a radical achievement. If one looks at the iconography of evangelical churches in Latin America with their clear streams, bright flowers and protective shepherds, the desire for images of cleansing and of the human and familial scale is evident. ... Being is a form of doing, and it is macho social 'science' which inter alia, prevents us from seeing how and when that can be so. ${ }^{14}$

Mention of 'macho social science' calls for an important aside. David was particularly attentive to the gender politics of Pentecostalism, which advance subtle forms of cultural renegotiation between men and women rather than open confrontation. He outlined the processes by which women were empowered in the realms of the church, home and outside work and those by which men are domesticated, drawn away from a destructive world of drink, drugs, promiscuity, and violence. Such practices ensure family stability rather than a breakdown that would tip women and children over the edge into absolute poverty. ${ }^{15}$ Elsewhere he noted the importance of female scholarship in highlighting these gendered dynamics, observing: 'After all, these movements appealed, like early Christianity, to women and feminised men. Male investigators quite often operate tests of political rectitude whereas women understand a revolution in the life-world and a reformation of manners and morals. ${ }^{16}$ While he commended several female scholars: Birgit Meyer, Diane Austen-Broos, Virginia Garrard-Burnett and Elizabeth Brusco it was surely modesty that prevented him from naming his wife, Bernice, as his most important influence. More than any other scholar her nuanced work on what she called the 'Pentecostal gender paradox' explained how by sidestepping starkly counterhegemonic action, Pentecostalism enables women to positively shift gender relations in ways that are non-threatening to men. ${ }^{17}$ Here we see the most explicit example of, to coin David's phrase,

\footnotetext{
${ }^{12}$ Martin, Forbidden, 15.

13 Martin, Forbidden, 1.

${ }^{14}$ Martin, Forbidden, 6-7.

15 Martin, Forbidden, 39-46.

${ }^{16}$ D. Martin, 'Review of Becoming Sinners' by Joel Robbins, Journal of Religion in Africa, 35, 1 (2005), 123.

${ }^{17}$ B. Martin 'The Pentecostal Gender Paradox', in R. K. Fenn (ed.), The Blackwell Companion to the Sociology of Religion. (Oxford: Blackwell, 2001).
}

Pentecostals 'altering what was in their capacity to alter'. Bernice's chapter on Pentecostalism in Latin America for Paul Heelas' edited collection Religion, Modernity and Post Modernity (1998), deeply attentive to issues of gender, remains one of the most convincing explanations of the religion's appeal to date. ${ }^{18}$

Following his discussion of concepts and methodology, David proceeded to initiate the reader into the world of the Pentecostal believer. In an eye-catching passage he set the scene, introducing Southern Pentecostals in a manner that challenges western academic preconceptions of Church: In what used to be called the Third World, the World Council of Churches'share of the Protestant constituency has dropped, and a protean indigenous Christianity has emerged indifferent to the agenda of the Western theological intelligentsia. Jürgen Moltmann is not regular fare among South African Zionists or the vast crowds of pilgrims attending the Temple of La Luz del Mondo, Guadalajara. ${ }^{19}$

The subsequent sections of the book revealed a profound grasp of who Pentecostals were, the precariousness of their existence, and how their social position determined their theology and practice. Mostly, they were: 'the respectable poor, but with variant forms in the middle class. Typically, they are foremen, artisans, domestic servants, nightwatchmen, small vendors'. ${ }^{20}$ They comprised 'myriads of tiny groups, some no more than a single home or shack attached to a home in a poor suburb. The suburb of La Pinta in Santiago is honeycombed with these, and so are the hills above the road snaking past Tijuana in Baja California. They are built by the poor for themselves and for whoever will join them. They have titles like 'Voice in the Desert' or 'Prince of Peace'. Inside them, the pastor-husband speaks in the evening from a makeshift podium only a few feet from the chicken run, while his wife maybe preaches in the street when the children emerge from school. ${ }^{21}$ Challenging the scholarly overemphasis on Catholic base communities David reminded us that 'Pentecostals are an option of the poor rather than the liberationist 'option for the poor' ${ }^{22}$ He had a particular empathy for the local leaders beginning with their social an appreciation of their vulnerability: 'the Pentecostal pastor more often than not has to keep his head down because his voice would not be heard, and because if it was raised too loudly his subsequent disappearance would not be noticed'. ${ }^{23}$ But more than this he admired their creativity, their desire for selfimprovement and ability to learn new skills in architecture,

\footnotetext{
${ }^{18}$ B. Martin, 'From Pre- to Post-Modernity in Latin America: The Case of Pentecostalism', in P. Heelas (ed.), Religion, Modernity and Post-Modernity. (Oxford, Blackwell, 1998).

${ }_{19}$ Martin Forbidden, 26.

${ }^{20}$ Martin, Forbidden, 37.

${ }^{21}$ Martin, Forbidden, 56.

22 Martin, Forbidden, 38.

23 Martin, Forbidden, 41.
} 
building, writing public speaking, and fund-raising: You can see such people all over the expanding evangelical world, often burly, square jawed and beetle-browed. They are God's salesmen with noses to the grindstone, exuding an Edwardian confidence and assurance, because they know they have made everything they have - and that God has 'made' them. ${ }^{24}$ Drawing on a historical perspective he observed: 'If you pursue the genealogies of Anglican hierarchs, they often lead back to enthusiastic lay dissenters who were (maybe) part of some English (or Welsh) 'buried intelligentsia'. ${ }^{25}$

Striking was his comprehension of the power of religious experience and religious language, and his ability to explain Pentecostalism in its own words: Lives come to be valued through the experience of being personally delivered to the core of your being, which is what is meant by the familiar phrase about responding to your 'personal saviour' - a God who is likewise 'personal' and 'in all points as you are'. Evangelical religion provides empowerment through its offer of healing, its demand for responsibility, and its invitation openly to affirm and express. For people to be openly addressed in the evangelical language of persons is to be spoken to in terms that truly speak to their condition, confirming beyond the shadow of the doubt their dignity, worth and significance ... Persons are not only affirmed as persons, but called upon to make judgements about themselves and about their own lives. By extension, they are encouraged to make their own judgements in each and every sphere ...

Personal address and the call to a comprehensive betterment must include complete cancellation of all inherited and acquired debts. The phrase 'forgive us our debts' resonates with special power where-ever people are enmeshed in every kind of bondage and indebtedness. If in the past you violated your own self or haplessly co-operated in its violation, you are cut free from that entanglement'. ${ }^{26}$ David grasped how the experience of being born again and 'touched' by the Holy Spirit could be so profound that it wrenched lives out of spirals of abuse and self-loathing, setting the believer in a caring community where they could discover gifts and talents they never knew they had.

As a doctoral student and, subsequently, young academic, working on the missionary encounter and then African Pentecostalism in Zimbabwe I did not encounter the resistance to my chosen subject that David had done thirty years earlier. From the outset of the nationalist era in the 1960s when professional African history came into being, Africanist historians had been interested in religion, even if they had read it in rather one-dimensional terms as resistance. In their quest for a usable past, they wrote about African independent churches led by great African prophets who were turned into proto-

\footnotetext{
$\overline{24}$ Martin, Forbidden, 53.

${ }_{25}$ Martin, Forbidden, 64.

${ }^{26}$ Martin, Forbidden, 45-46.
}

nationalists and freedom fighters as a part of a teleological narrative of progress towards independence. But the passage of time showed that most African Christians continued to adhere to the historic mission churches and scholars began to study their legacy. By reading out African voices from missionary sources, the collection of oral history and the observation of African appropriations of mission Christianity, historians and anthropologists came to grasp that the real agents of Africa's Christianisation were Africans themselves: evangelists, catechists, labor migrants, teachers, and Bible women. By the 1980s scholars were writing the history of missions with emphasis on the creativity of African Christians who indigenized the faith. ${ }^{27}$ They did so by drawing on broader developments in social and cultural history which was interested in the ordinary, the everyday and the lived. ${ }^{28}$ It was thus quite possible to write a peopled religious history in a similar manner to the way David was doing his sociology. The only problem was that given the dominance of the historic mission churches in Africa scholars did not initially grasp what they were dealing with when they came across Pentecostals. Adrian Hastings christened the zealous young students he met at the University of Zimbabwe in the early 1980s as representatives of a 'new independency' while the Dutch anthropologist Rijk van Dijk initially cast the brash street evangelists he encountered in urban Malawi as 'young Puritan preachers'. ${ }^{29}$ Although an Anglican, I had taught at a Pentecostal mission school in Zimbabwe (1986-89), and was thus able to recognize a Pentecostal when I saw one. My contemporaries, Birgit Meyer and Ruth Marshall, got the idea too.

David (and Bernice's) work on Pentecostalism came as a breath of fresh air. Hitherto, Africanists had not had much of their own scholarship to think with save Paul Gifford's rather reductive The New Crusaders, which cast the contemporary effervesce of charismatic religion in Southern Africa as product of the imperialism of the US Religious Right, a replay of the missionaries as handmaids of empire debate set in the late Twentieth Century. ${ }^{30}$ Though, in dialogue with David's work, Gifford went on to write an increasingly nuanced set of studies on current African Christian expressions. ${ }^{31}$ My own work owed much to David's insights, starting with the title of my

\footnotetext{
${ }^{27}$ D. Maxwell, 'Writing the History of African Christianity', Journal of Religion in Africa, 36, 4, (2006); 'The Missionary Movement in African and World History: Mission Sources and Religious Encounter', The Historical Journal, 58, 4, (2015). My own supervisor, Terence Ranger, had done much of this pioneering work.

${ }^{28}$ P. Burke, What is Cultural History? (London: Polity, 2019 3rd Edition).

29 A. Hastings, African Catholicism. (London, SCM Press, 1989) 33; R. Van Dijk, 'Young Puritan Preachers in post-Independence Malawi, Africa, 62, 2 (1992).

${ }^{30}$ P. Gifford, The New Crusaders. Christianity and the New Right in Southern Africa. (London: Pluto, 1991).

${ }^{31}$ See for instance P. Gifford, Ghana's New Christianity. Pentecostalism in a Globalising African Economy. (London: Hurst \& Co., 2004).
} 
second book, African Gifts of the Spirit, which was an attempt to both capture the centrality of religious resources to Pentecostalism and the agency of believers. Throughout the book, which was a study of the Zimbabwe Assemblies of God Africa (ZAOGA) I placed a strong analytical focus on prayer; healing and family stability as a value for the poor; and on the achievement of personal security, rather than prosperity, in the era of neoliberal structural adjustment programs. When I told David that I had recorded prayers, testimonies and sermons he suggested that I construct a lexicon of key words and images. The results were fascinating, revealing a preponderance of images of refuge, security and protection such as those invoked by a young preacher I encountered in suburban Harare: 'Witches will come but they won't touch you. The blood of Jesus is a Durawall [a proprietary brand of pre-cast concrete security walling]. God intervenes like a strong wrestler in touch wrestling, ${ }^{32}$ But there were also more upbeat allusions to status, authority, victory and betterment. Having taken refuge in the Pentecostal assembly believers remade themselves, coming to view their lives in a more positive light. In another suburban meeting, a woman pastor pronounced: 'We are priests for our families, breaking the traditions of our forefathers, saving our families from calamities: daughters not marrying, sickness, poverty'. 33 Inspired by David's insights into the Pentecostal pastorate I devoted a good deal of attention to ZAOGA's leader, Ezekiel Guti, a former carpenter, who built a township-based prayer band into a modern transnational denomination with several hundred thousand members and assemblies throughout Africa as well as in Britain and US. Fascinating was his canny transformation of US donations into personal patronage; his Machiavellian ability to neutralize aspiring lieutenants and replace them with family members; and his creative construction of a leadership cult via the elaboration of a highly partisan canonical history. Equally remarkable was his preaching which was a combination of Black pride, cultural nationalism, and hardnosed Pentecostal pragmatism - a willingness to engage in the kind of cultural criticism that contemporary evangelical missionaries would love to practice but no longer dare:

[O] ur people want to be servants of white people. They trust whites better than our own people. This is what we call third world mentality ... Don't go to Europe and learn their ungodly things. Learn what they used to do before [they were backslidden] ... One day I saw another man carrying his car battery and asked him where he was going and he said, 'I am taking my battery to trustworthy white people.' You see! We must change our minds and be faithful to one another. ... We will trust our skin. Only righteousness can change our minds.

\footnotetext{
32 D. Maxwell, African Gifts of the Spirit: Pentecostalism and the Rise of a Zimbabwean Transnational Religious Movement . (Oxford, James Currey, 2006), 188.

${ }^{33}$ Maxwell, African Gifts, 210.
}

Without righteousness, we will live in a country telling lies to each other'. 34

The final book in David's trilogy, Pentecostalism: The World is Their Parish (2002) was global in scope, drawing out commonalities in context and causation, and highlighting its common character in communities across the global South. ${ }^{35}$ The study pointed towards two sub-disciplinary developments in which he played a part. The first was the Anthropology of Christianity. When Social Anthropology moved from the study of the exotic 'other' to the quotidian and the familiar, so Christianity became a subject worthy of systematic attention. ${ }^{36}$ It was reconceptualized as having something akin to its own culture, a set of ideas, rituals and practices that enable it to be studied across cultures as well as in localized forms. As Susan Harding observed, Anthropologists had consciously ignored Christianity, regarding it as a 'repugnant cultural other' whose consideration stood in contrast to the 'politically sympathetic' more familiar subjects of study such as 'ethnic and racial minorities, workers, tribal and peasant peoples, the colonised and the postcolonials'. ${ }^{37}$ David had long been irked by scholarly neglect of the religious choices of the majority in favour of the study of supposedly authentic cults of so-called primitive or ethnic religion. In the opening section of Forbidden Revolutions, he wrote: '... of course, part of the problem is that the world evoked [by Pentecostals] is not quite foreign enough. Were it comprised of ancestor worshipers in Vietnam or shamans in Siberia, we would suspend our judgement and not impose our categories, ${ }^{38}$ He thus encouraged the work of Fenella Cannell and Matthew Engelke, two pioneering Anthropologists of Christianity, based at the London School of Economics, which by the end of his career there, had allowed the study of religion 'a secure institutional footing'. 39 Cannell examined Christianity's various dualisms, especially the tension between its embodied and transcendent aspects. ${ }^{40}$ While, by means of an ethnography of an independent church in Zimbabwe, Engelke explored the conundrum of a religion fixated with escaping from materiality but which nevertheless needs representations in words and things to make God present. $^{41}$ David also actively promoted the third pioneer, Joel

\footnotetext{
${ }^{34}$ E. Guti, 'Lift up a Standard for the People', National Stadium, Harare, 7 February 1988, The Sacred History of ZAOGA Forward in Faith pt. 1, Waterfalls, ZAOGA c.1988 cited in Maxwell, African Gifts, 188.

35 D. Martin, Pentecostalism: the world is their Parish. (Oxford, Blackwell, 2001).

${ }^{36}$ T. Jenkins, 'the Anthropology of Christianity: Situation and Critique,' Ethnos, 77, 4, 462.

37 S. Harding, 'Representing Fundamentalism: the problem of the repugnant cultural other', Social Research, 58, 2, (1991), 372

38 Martin, Forbidden, 13-14.

${ }^{39}$ Martin, Education, 156.

${ }^{40}$ F. Cannell (ed.) The Anthropology of Christianity (Durham NC: Duke University Press, 2007).

${ }^{41}$ M. Engelke, A Problem of Presence. Beyond Scripture in an African Church, (Berkeley: University of California Press, 2007).
} 
Robbins, then based at the University of California, San Diego, writing a long review of his book Becoming Sinners: Christianity and Moral Torment in a Papua New Guinea Society (2005) which was a study of the conversion to charismatic Christianity of an island community. ${ }^{42}$ Published somewhat exceptionally in an Africanist area studies journal, The Journal of Religion in Africa, David's piece brought to Africanists Robbins' important assertion that social anthropologists had consistently underplayed the significance of rupture in Protestant conversion because their tendency towards 'continuity thinking, ${ }^{43}$ In the subsequent years following that review, numerous scholars published articles in the JRA engaging with Robbins' work on conversion. ${ }^{44}$

David's focus on the 'big story' of Pentecostalism as a world religion also inspired a scholarly intervention into the field of World Christianity from myself and two other colleagues in Cambridge, Joel Cabrita and Emma Wild-Wood. Shedding the Eurocentric baggage of Mission Studies, scholars in this relatively new sub-discipline focus on the seizure and vernacularizing of Christianity by local communities in the global South and celebrate as reverse mission its triumphal re-export back to the West in the hands of Diaspora or Southern missionaries. While the notion of World Christianity has prompted much good work it remains under conceptualised, stimulating the multiplication of local studies with little attempt to identify patterns of inculturation across the globe. Taking a leaf from David's work our edited collection Relocating World Christianity was a call for greater attention to comparison, connection and consciousness in the spread of global Christianity, and in particular, what is 'universal' about the faith. ${ }^{45}$

What made David's work on Pentecostalism so persuasive was his capacious grasp of how religion touched the human persona. Although grounded in his own experience of revivalism he also brought to his work an immense erudition. Drawing insights from History, Music, Theology, Social Anthropology and the Fine Arts he shed light on how Protestant religion could sustain, transform and offer hope. His writing was wonderfully humane.

Open Access This article is licensed under a Creative Commons Attribution 4.0 International License, which permits use, sharing, adaptation, distribution and reproduction in any medium or format, as long as you give appropriate credit to the original author(s) and the source, provide a link to the Creative Commons licence, and indicate if changes were made. The images or other third party material in this article are included in the article's Creative Commons licence, unless indicated otherwise in a credit line to the material. If material is not included in the article's Creative Commons licence and your intended use is not permitted by statutory regulation or exceeds the permitted use, you will need to obtain permission directly from the copyright holder. To view a copy of this licence, visit http://creativecommons.org/licenses/by/4.0/.

Publisher's Note Springer Nature remains neutral with regard to jurisdictional claims in published maps and institutional affiliations.

David Maxwell is Dixie Professor of Ecclesiastical History and Fellow of Emmanuel College in the University of Cambridge. His most recent major publication is: D. Maxwell, J. Cabrita and E. Wild-Wood (eds.) Relocating World Christianity: Interdisciplinary Studies in Universal and Local Expressions of the Christian Faith (Leiden: E.J. Brill, 2017).

\footnotetext{
42 J. Robbins, Becoming Sinners: Christianity and moral torment in a Papua New Guinea Society. (Berkeley: University of California Press, 2004).

${ }^{43}$ D. Martin, 'Review of Becoming Sinners'. J. Robbins, 'Continuity Thinking and the Problem of Christian Culture', Current Anthropology, 48, 1 (2007). In 2005, David attended a lively seminar discussion of Robbins' work, organized by myself and Richard Werbner, hosted at the university of Manchester.

${ }^{44}$ I commissioned the review as the then Editor of the JRA, aware of David's great ability to range far and wide in his reviewing for The Times Literary Supplement and The Church Times.
}

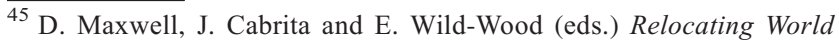
Christianity: Interdisciplinary Studies in Universal and Local Expressions of the Christian Faith (Leiden: E.J. Brill, 2017).
} 